\title{
Study on child labour in automobile workshops of Peshawar, Pakistan
}

\author{
H. Khan, ${ }^{1}$ A. Hameed ${ }^{2}$ and A.K. Afridi ${ }^{3}$

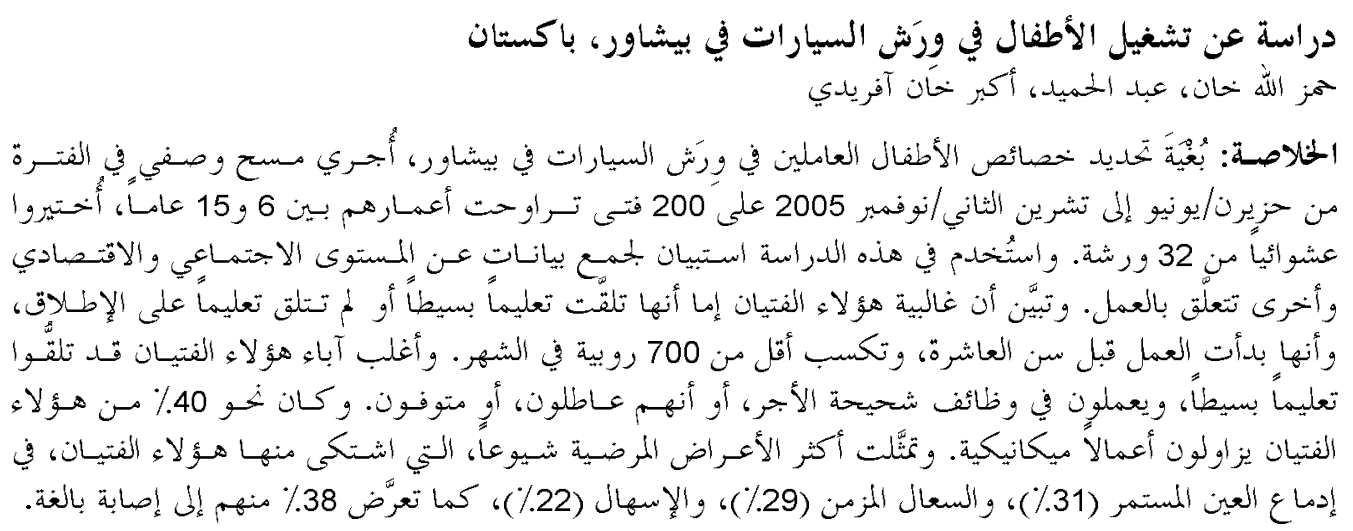

ABSTRACT To determine the characteristics of children working in car workshops in Peshawar, a descriptive survey was conducted from June to November 2005 of 200 boys (6-15 years) randomly selected from 32 workshops. A questionnaire was used to collect socioeconomic and work-related data. The majority of the boys had no or little education, had started work before the age of 10 years and earned $<700$ rupees/month. Most of their fathers had little education and were in poorly paid jobs, unemployed or deceased. About $40 \%$ of the boys were engaged in mechanical work. Watery eyes (31\%), chronic cough $(29 \%)$ and diarrhoea $(22 \%)$ were the commonest symptoms reported by the boys and $38 \%$ had had a major injury.

\begin{abstract}
Étude du travail des enfants dans les ateliers de réparation automobile de Peshawar au Pakistan

RÉSUMÉ Afin de déterminer les caractéristiques des enfants travaillant dans les ateliers de réparation automobile de Peschawar, une étude descriptive a été menée de juin à novembre 2005 auprès de 200 garçons, âgés de 6 à 15 ans, sélectionnés au hasard dans 32 ateliers. Les données socioéconomiques et d'ordre professionnel ont été collectées par le biais d'un questionnaire. Dans leur majorité, les garçons enquêtés n'avaient qu'une instruction très limitée, voire nulle, avaient commencé à travailler avant l'âge de 10 ans et gagnaient moins de 700 roupies par mois. Pour la plupart, les pères de ces enfants n'avaient qu'un très faible niveau d'instruction et étaient soit très mal payés, soit chômeurs ou décédés. L'activité d'environ $40 \%$ de ces garçons était en rapport avec la mécanique. Larmoiement (31\%), toux chronique $(29 \%)$ et diarrhée $(22 \%)$ étaient les symptômes les plus fréquemment rapportés par ces garçons et $38 \%$ présentaient une lésion majeure.
\end{abstract}

${ }^{1}$ Khyber Medical College, Peshawar, Pakistan (Correspondence to H. Khan: hamza_kmc@yahoo.com; hamzakmc@gmail.com).

${ }^{2}$ Department of Child Health; ${ }^{3}$ Department of Community Medicine, Khyber Medical College, Peshawar, Pakistan.

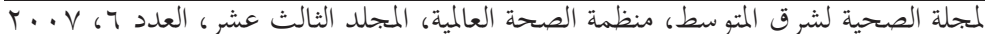




\section{Introduction}

Pakistan's exports have suffered heavy losses due to its denunciation for use of children in industry on the premise that it destroys their childhood and desire for betterment. The children in this area are deprived and are trapped between working for the family and the desire to live the life of a child with hopes, dreams and aspiration for a better future. However, it has been argued that making them jobless may only aggravate their health and financial problems and will not improve their social and economic status [1].

According to unofficial estimates, during 2004-05, 8-10 million children in Pakistan were employed in various sectors. Officially, 3.5 million children were acknowledged to be a part of the labour force. It has been reported that child labour among 10-14years-olds increased to 2.0 million during 1992-93 from 1.8 million during 1990-91 [2]. The growth in the number of girl workers is higher than that in boys. In urban areas, the services sector employs $52 \%$ of all children, followed by the manufacturing sector, which employs 38\%. Moreover, it has been reported that about $70 \%$ of the children work longer than normal working hours (35 hours/week) [2].

Child labour and corporal punishment are believed to be the major causes of a Sindh school drop-out rate of over $50 \%$, while similar reasons are also responsible for children leaving school in other provinces [3].

In the city of Peshawar, there are hundreds of motor vehicle repair workshops, where huge numbers of children work without any safety measures. A considerable number of children work in these workshops out of financial necessity because of the low socioeconomic status of their families [4].

This study aimed to determine the characteristics of children working in automo- bile workshops in Peshawar, Pakistan, their reasons for working and the adverse health effects experienced, in order to add to the voice against the child labour.

\section{Methods}

This study was conducted in automobile workshops located on the university road, ring road, hajj camp and bazaar area in Peshawar from June to November 2005. The sample comprised only boys, which reflects the Pashtun culture that requires men to work and earn for the whole family without any or very little contribution from women.

A total of 200 boys with ages ranging from 6 to 15 years were randomly selected from 32 randomly selected automobile workshops of Peshawar. The inclusion criteria were that the individuals: were $5-15$ years old, could be identified unambiguously as being within that age range, and were working only in the automobile workshop rather than any other type of labour.

Respondents were interviewed during their work time after prior permission from the head of the workshop. They were interviewed using a predesigned questionnaire prepared in accordance with the objectives of the study. Our medical interviewers visited the workshops with stethoscope and sphygmomanometer and carried out some clinical examinations of the children to confirm the systems involved in a particular disease the boys were complaining of.

The questionnaire sought information about age, nature of work (assigned to them in the workshop), monthly wage, exposure to dangerous environment at work and chronic symptoms that children were suffering from. It also included information about the father's profession, family size and income. Major accident/injury was defined as any permanent loss to an organ, or loss of hearing, or fracture of bones, or 
a permanent physical disability and injury that caused anatomical distortion.

\section{Results}

Table 1 shows selected characteristics of the boys working in automobile workshops. A large proportion $(34 \%)$ had never been to school while $41.5 \%$ had dropped out before class five (age 10 years). For $66 \%$ of the respondents, the average monthly income was $\leq 700$ rupees. The age of starting work was $<10$ years for $76.5 \%$ of the children.

The reasons for starting work and leaving school were: to help the family financially, either going on own accord (40\%)

\begin{tabular}{|c|c|c|}
\hline Characteristic & $\begin{array}{l}\text { No. of boys } \\
(n=200)\end{array}$ & $\%$ \\
\hline \multicolumn{3}{|l|}{ Age group (years) } \\
\hline $6-9$ & 36 & 18.0 \\
\hline $10-12$ & 73 & 36.5 \\
\hline $13-15$ & 91 & 45.5 \\
\hline \multicolumn{3}{|l|}{ Education } \\
\hline Never went to school & 68 & 34.0 \\
\hline $\begin{array}{l}\text { Dropped out before class } \\
\text { five (age } 10 \text { years) }\end{array}$ & 83 & 41.5 \\
\hline Completed primary school & 34 & 17.0 \\
\hline $\begin{array}{l}\text { Completed middle school } \\
\text { or higher }\end{array}$ & 15 & 7.5 \\
\hline \multicolumn{3}{|l|}{$\begin{array}{l}\text { Average monthly wage } \\
\text { (rupees) }\end{array}$} \\
\hline$<500$ & 78 & 39.0 \\
\hline $500-700$ & 53 & 26.5 \\
\hline $701-1000$ & 40 & 20.0 \\
\hline$>1000$ & 29 & 14.5 \\
\hline \multicolumn{3}{|l|}{ Age at starting work (years) } \\
\hline$<8$ & 83 & 41.5 \\
\hline $9-10$ & 70 & 35.0 \\
\hline $11-12$ & 22 & 11.0 \\
\hline $13-15$ & 25 & 12.5 \\
\hline
\end{tabular}

and being sent by parents $(26.5 \%)$ (Table $2)$. The largest proportion was involved in mechanical work (42.5\%).

Table 3 shows the family background of the boys. Just over half of the fathers of the boys had had no schooling and were illiterate; only $11 \%$ had high school or higher education. As regards profession, $20 \%$ of the fathers were farmers, $16.5 \%$ were unskilled labourers, $15.0 \%$ were unemployed and $10 \%$ were dead. About $85 \%$ of the boys came from large families (5 or more children). Father's monthly income was less than 3000 rupees/month for $33.3 \%$ of cases.

The symptoms recorded in the 200 boys were: watery eyes $(31.0 \%)$, chronic cough $(29.0 \%)$, diarrhoea $(22.0 \%)$, runny nose $(18.0 \%)$, skin lesions and fatigue (each $17.5 \%$ ), chronic backache (16.5\%), breathlessness (13.5\%) and no symptoms in $23.0 \%$ cases. Some suffered from more than 1 symptom. Of the 200 boys, 76 (38\%) had

Table 2 Reason for starting work and nature of the job

\begin{tabular}{lrr}
\hline Variable & $\begin{array}{c}\text { No. of boys } \\
(\boldsymbol{n}=\mathbf{2 0 0})\end{array}$ & \multicolumn{1}{c}{$\%$} \\
\hline $\begin{array}{l}\text { Reason for starting work } \\
\text { Went on own accord }\end{array}$ & & \\
to help family financially & 80 & 40.0 \\
Sent by parents to help & & \\
family financially & 53 & 26.5 \\
Own desire to work & 17 & 8.5 \\
Dropped out of school & 13 & 6.5 \\
Other & 37 & 18.5 \\
Nature of job & & \\
Mechanical work & 85 & 42.5 \\
Painting & 26 & 13.0 \\
Welding & 21 & 10.5 \\
Dent repair & 12 & 6.0 \\
Electrical & 9 & 4.5 \\
Other & 47 & 23.5 \\
\hline
\end{tabular}

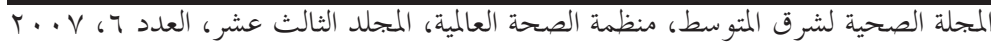


Table 3 Family background of the boys working in automobile workshops in Peshawar

\begin{tabular}{lrr}
\hline Variable & $\begin{array}{c}\text { No. of boys } \\
(\boldsymbol{n}=\mathbf{2 0 0})\end{array}$ & \multicolumn{1}{c}{} \\
& 31 & 15.5 \\
\hline Family size (no. of children) & & \\
$1-4$ & 128 & 64.0 \\
$5-7$ & 41 & 20.5 \\
$>7$ & & \\
Father's profession & 41 & 20.5 \\
Farmer & 10 & 5.0 \\
Shopkeeper & 3 & 1.5 \\
Civil servant & 27 & 13.5 \\
Skilled worker & 33 & 16.5 \\
Unskilled labourer & 30 & 15.0 \\
Unemployed & 12 & 6.0 \\
Private sector worker & 20 & 10.0 \\
Dead & 24 & 12.0 \\
Other & & \\
Father's education (n = 180) & & \\
$\quad$ No schooling & 92 & 51.1 \\
Primary school & 46 & 15.6 \\
$\quad$ Middle school & 23 & 12.8 \\
High school and above & 19 & 10.6 \\
\hline
\end{tabular}

Table 4 History of major injuries recorded in the boys working in automobile workshops in Peshawar

\begin{tabular}{lrr}
\hline History of injury & No. of boys & $\%$ \\
\hline History of major injury & & \\
recorded $(n=200)$ & 76 & 38.0 \\
$\quad$ Yes & 124 & 62.0 \\
$\quad$ No & & \\
If yes, nature of injury $(n=76)$ & 44 & 57.9 \\
$\quad$ Severe cut wounds & 6 & 7.9 \\
$\quad$ Blunt injury & 16 & 21.1 \\
Burn & 8 & 10.5 \\
Fracture & 2 & 2.6 \\
$\quad$ Other & & \\
\hline
\end{tabular}

had a major accident, the commonest being severe cuts $(60 \%)$ (Table 4$)$.

\section{Discussion}

In Pakistan it is estimated that $10 \%-19 \%$ of children are working. The estimate for Egypt was $6.5 \%$ of children $6-14$ years in $1980[2,4]$. The present study aimed to raise awareness of the problem of child labour in our city, and to explore some of the characteristics of the boys related to their working. Although the number of boys included was small, the study still provides useful information regarding child labour in the area.

Children ranging in age from 6 to 15 years were selected. This is the age that children need to be in school but many factors force them to drop out and join the labour force, usually earning only low wages. Helping to support the family is a main reason for this. Indeed, $13 \%$ of the population of Pakistan earn less than US\$ 1 per day so there is tremendous pressure to supplement income however possible [3]. The father's profession can directly affect the life of a child and a father's inability to support his family can lead to children being forced to go out to work. In the present study, the fathers of the boys working in the automobile workshops were mainly in low level jobs that did not pay adequate salaries; for about a third of the boys their father's monthly income was less than 3000 rupees/month. Furthermore, $15 \%$ of the fathers were unemployed and $10 \%$ were dead, situations that can further put pressure on children to work in order to help provide for the family. The low level of jobs of the fathers may be a result of the low level of education that they had. The majority of the fathers were illiterate. Our study correlates with other studies showing 
that the parents of children working in factories had low educational levels and were either unemployed or employed in unskilled occupations [5].

Symptoms recorded in the boys were: watery eyes, chronic cough, diarrhoea, runny nose, skin lesions, fatigue and chronic backache. These are indicative of possible exposure to polluted, hazardous environments and hard labour. Ravikumara and Sandhu reported that bowel diseases were common in working children and accounted for nearly $30 \%$ of total cases [6]. Another study showed an increased prevalence of childhood dermatosis especially in working children [7]. Diarrhoeal diseases are a leading cause of mortality and morbidity, especially among children in developing countries. Many of the infectious agents associated with diarrhoeal disease are waterborne [8]. Regarding asthma/dyspnoea in working children, a study from Puerto Rico revealed that $25 \%$ of child workers were affected by this chronic condition [9]. In our study, $29 \%$ of the boys had a chronic cough and $13 \%$ reported breathlessness, both of which could be indicative of asthma and clearly show a considerable proportion of boys suffered from respiratory problems. Major injuries were recorded in $38 \%$ of the boys in our study and clearly show the real risks children face when working in unsafe environments, such as car repair workshops. Other studies also show that mild traumatic brain injury is frequently encountered in working children [10].

The children in our study are trapped and deprived of their childhood and the chance to aspire for a better future. Such children are caught in a vicious cycle; they need to work to help provide for their families and as a result are unable to attend school and get an education which could provide them with the skills to better themselves and break out of the poverty trap. Not only are they deprived of the means (education) to achieve a better life, but by working, particularly in unsafe environments, their health is being endangered, and they may also be subject to abuse and exploitation [11]. This may further limit their ability to escape the poverty trap. Poverty is clearly a key factor and is the issue that must be addressed to try and eliminate child labour.

\section{References}

1. Tabassum F, Baig LA. Child labour a reality: results from a study of a squatter settlement of Karachi. Journal of the Pakistan Medical Association, 2002, 52(11):507-10.

2. Jafri SM, Raishad. Some dimensions of child labour in Pakistan. Pakistan development review, 1997, 36(1):69-86.

3. The state of the world's children 2005. Childhood under threat. New York, United Nations Children's Fund, 2005:104-45.

4. Zakir $S$ et al. Lead poisoning in children working at automobile workshops in Peshawar (Pakistan). Online journal of biological sciences, 2002, 2(6):390-1.
5. Ali M et al. Street children in Pakistan: a situational analysis of social conditions and nutritional status. Social science \& medicine, 2004, 59(8):1707-17.

6. Ravikumara M, Sandhu BK. Epidemiology of inflammatory bowel diseases in childhood. Indian journal of paediatrics, 2006, 73(8):717-21.

7. Lewis-Jones S. Quality of life and childhood atopic dermatitis: the misery of living with childhood eczema. International journal of clinical practice, 2006, 60(8):98492.

8. Clasen $\mathrm{T}$ et al. Interventions to improve water quality for preventing diarrhoea.

المجلة الصحية لشرق المتوسط، منظمة الصحة العالمية، المجلد الثالث عشر، العدد ب، V... 
Cochrane database systematic reviews, 2006, 3:CD004794.

9. Seguinot-Medina S, Rivera-Rentas A. Risk assessment and community participation model for environmental asthma management in an elementary public school: a case study in Puerto Rico. International journal of environmental research and public health, 2006, 3(1):76-85.
10. Cook RS et al. Mild traumatic brain injury in children: just another bump on the head? Journal of trauma nursing, 2006, 13(2):58-65.

11. Child abuse and crimes against children in North-West Frontier Province (Pakistan). Peshawar, NGO Coalition on Child Rights, 1998.

The state of the world's children 2007: women and children, the double dividend of gender equality

This UMICEF report, which can be downloaded at: http://www.unicef. org.uk/publications/pub_detail.asp?pub_id=111, intends to provide a road map to accelerate progress towards gender equality and empowering women. It describes the lives of women around the world. Gender equality and the well-being of children go hand in hand: when women are empowered to live full and productive lives, children prosper; when women are denied equal opportunity within a society, children suffer.

Despite substantial gains in women's empowerment since the Convention on the Elimination of All Forms of Discrimination against Women was adopted by the UM General Assembly in 1979, gender discrimination remains pervasive in every region of the world. It appears in the preference for sons over daughters, limited opportunities in education and work, and gender-based physical and sexual violence.

Other, less obvious, forms of gender discrimination can be equally destructive. Institutional discrimination is hard to identify and rectify. Cultural traditions can perpetuate discrimination as gender stereotypes remain widely accepted and go unchallenged.

Eliminating gender discrimination requires enhancing women's influence in the decisions that shape their lives and those of children in three distinct arenas: the household, the workplace and the political sphere. A change for the better in any one of these influences women's equality in the others and has a positive impact on children everywhere. 